\title{
Pelatihan Pembuatan Google Form untuk mendapatkan Feedback Pelanggan Cafe Rumah Kopi 55
}

\author{
Sabrina Aulia Rahmah ${ }^{1 *}$, Jovi Antares ${ }^{2}$, Buyung Solihin Hasugian ${ }^{3}$ \\ Universitas Dharmawangsa, Jl. K.L Yos Sudarso No. 224, Glugur Kota, Kec. Medan Barat, Kota \\ Medan, Sumatera Utara 20115 \\ Email: sabrinaaulia@dharmawangsa.ac.id ${ }^{1 *}$
}

(Diajukan: 27 April 2021, Direvisi: 24 Juni 2021, Diterima: 09 Juli 2021)

\begin{abstract}
ABSTRAK
Berkembangnya media teknologi informasi dan komunikasi yang sangat pesat dan sangat maju dan diminati masyarakat yang mengacu pada sumber informasi sudah tidak asing lagi yaitu penggunaan internet Penggunaan jasa layanan internet di Indonesia terus mengalami peningkatan dan perkembangan. Manfaat internet sebagai salah satu solusi untuk mengefisienkan berbagai kepentingan telah dirasakan oleh banyak kalangan. Salah satunya melahirkan media baru yang di sebut Google Form. Pengabdian yang akan dilaksanakan di salah satu cafe yang ada di kota medan yaitu cafe Rumah Kopi 55 berupa pendampingan dan arahan kepada pengelola cafe dalam membuat aplikasi Google Form yang dapat digunakan oleh pelanggan secara cepat dengan hanya mengakases link yang diberikan, yang mana aplikasi ini digunakan untuk mendapatkan Feedback pelanggan terhadap sistem pelayanan cafe yang ada sekarang agar dapat membuat cafe lebih maju lagi dan berkembang. Metode yang digunakan pada kegiatan ini digunakan pelatihan dengan interaksi dua arah antara tim pengabdian dan pihak pengelola cafe. Hasil yang diperoleh dalam pengabdian adalah tercipta suatu aplikasi feedback untuk pelanggan terhadap pelayanan di cafe Rumah Kopi 55. Namun hingga saat ini pihak pengelola cafe belum menerapkan aplikasi yang telah diberikan d. Salah satu dampaknya yaitu kemudahan bagi pelanggan dalam memberikan feedback serta memberikan kemudahan bagi cafe Rumah Kopi 55 dalam meningkatkan pelayanan dan manajemen berdasarkan feedback yang diberikan.
\end{abstract}

Kata Kunci: Google Form, Feedback, Pelanggan

ABSTRACT

The development of information and communication technology media that is very rapid and very advanced and in demand by the public who refers to information sources is already familiar, namely the use of the internet. The use of internet services in Indonesia continues to increase and develop. The benefits of the internet as a solution to streamline various interests have been felt by many people. One of them gave birth to a new media called Google Form. The service that will be carried out at one of the cafes in the city of Medan, namely the Rumah Kopi 55 cafe in the form of assistance and direction to cafe managers in making a Google Form application that can be used by customers quickly by only accessing the given link, where this application is used to get customer feedback on the existing cafe service system in order to make the cafe more advanced and growing. The method used in this activity is training with two-way interaction between the service team and the cafe manager. The results obtained in the service are the creation of a feedback application for customers on services at the Kopi Rumah cafe 55. However, until now the cafe manager has not implemented the application that has been given $d$. One of the impacts is the convenience for customers in providing feedback and providing convenience for Rumah Kopi 55 cafe in improving service and management based on the feedback provided.

Keywords: Google Form, Feedback, Customers 


\section{PENDAHULUAN}

Perkembangan bisnis pada era globalisasi saat ini berbeda pada masa-masa sebelumnya. Hal ini dipengaruhi oleh aspek-aspek baik secara intern maupun ekstern. Faktor intern yang mempengaruhi perkembangan bisnis di Indonesia adalah berkembangnya tingkat kreativitas dan inovasi pada kehidupan masyarakat dan faktor ekstern yang mempengaruhi adalah berkembangnya kemajuan IPTEK yang dihadapi oleh masyarakat. Faktorr-faktor tersebut mempengaruhi bisnis-bisnis baik dari bisnis skala kecil maupun bisnis skala besar. Google Form merupakan fasilitas open source dapat dimiliki oleh setiap orang. Dengan 1 (satu) Account Google memiliki banyak manfaat, diantaranya adalah bisa mengakses Google Form (Santilo, 2018). Google Form merupakan aplikasi yang memiliki tampilan simple dan usefriendly (mudah digunakan) bagi dosen. Ada beberapa penelitian yang diangkat dalam menggunakan aplikasi Google Form yaitu, Menurut Azis, (2020) Google Form digunakan dosen sebagai media evaluasi pembelajaran terhadap mahasiswa. Pemanfaatan Google Form digunakan untuk mendukung pengumpulan data untuk karya ilmiah mahasiswa akhir yang ada di Sekolah Tinggi Ilmu Ekonomi Boedi Oetomo Pontianak (Widayanti, 2021).

Manfaat dari Google Form untuk aktifitas sehari-hari adalah (Technology, 2016) yaitu Distribusi dan tabulasi online dan real-time, Real time collaboration: 50 orang dapat bekerja dalam satu berkas dalam satu waktu. Setiap perubahan disimpan secara otomatis dan Aman: menyimpan berkas penting atau tugas sekolah tidak takut hilang atau rusak atau terkena virus.

Salah satu bisnis yang banyak diminati khususnya masyarakat Indonesia adalah bisnis warung kopi/coffee shop. Hal ini dikarenakan semakin meningkat masyarakat Indonesia dalam mengkonsumsi kopi serta mudahnya dalam mendapatkan bahan baku kopi. Salah satu bisnis yang bergerak dalam penjualan minuman kopi adalah cafe Rumah Kopi 55. Cafe Rumah Kopi merupakan salah satu dari sekian banyak bisnis warung kopi/coffee shop yang ada di Indonesia, terutama di Kota Medan Sumatera Utara.

Dalam menjalankan sebuah bisnis tingkat kepuasan pelanggan merupakan hal yang sangat penting dalam industri jasa maupun barang. Karena dalam industri, pelayanan yang dapat memuaskan konsumen akan memberikan imbalan yang menguntungkan, serta meningkatkan daya saing perusahaan maupun bisnis (Tedas, 2020; Iriawan, 2021).

Kepuasan adalah tingkat perasaan seseorang atau masyarakat setelah membandingkan hasil yang dirasakan dengan harapannya. Apabila hasil yang 
dirasakannya sama atau melebihi harapannya, akan timbul perasaan puas, sebaliknya akan timbul perasaan kecewa atau ketidakpuasan apabila hasil yang dirasakannya tidak sesuai dengan harapannya (Nuryuniarti, 2019).

Cafe Rumah Kopi 55 beralamat di Jalan Beringin 3 No.55, Helvetia, Kec. Medan Helvetia, Kota Medan, Sumatera Utara yang sudah menjalankan bisnis penjualan minuman kopi selama hampir satu tahun. Namun, dengan meningkatnya dan semakin banyak masyarakat mengkonsumsi minuman kopi, maka diperlukan peningkatan kualitas dalam menjalankan bisnis tersebut khususnya dalam segi pelayanan terhadap konsumen. Dalam pelaksanaannya, diperlukan feedback atau umpan balik dari konsumen guna dijadikan sebagai bahan evaluasi dan informasi dalam meningkatkan pelayanan.

Feedback atau umpan balik yang dilakukan oleh cafe Rumah Kopi 55 masih dilakukan secara manual. Artinya, feedback atau umpan balik yang diberikan oleh konsumen kepada pengelola cafe Rumah Kopi 55 dilakukan dengan cara penyampaian secara lisan kepada pihak pengelola atau melakukan tulis tangan pada selembar kertas. Hal ini dapat menjadi masalah karena tidak adanya pengelolaan dalam menerima feedback atau umpan balik yang diberikan oleh konsumen.

Dalam kemajuan teknologi saat ini sangat dibutuhkan sebagai penunjang kelancaran kegiatan dalam pengelolaan cafe Rumah Kopi 55. Salah satu solusi yang ditawarkan dalam masalah yang dihadapi cafe Rumah Kopi 55 dalam mengelola feedback atau umpan balik adalah dilakukan pembuatan Google Form dalam mengelola feedback atau umpan balik oleh konsumen. Google Form merupakan salah satu fasilitas teknologi berupa perangkat lunak yang ditawarkan oleh Google Corporote (Qwords, 2020). Google Form mampu mengelola dan sebagai sentra informasi yang diperlukan oleh pihak cafe Rumah Kopi 55 dalam menerima feedback atau umpan balik dari pelanggan.

Berdasarkan hasil pengamatan yang dilakukan di cafe Rumah Kopi 55 adalah konsumen yang datang berkunjung di cafe Rumah Kopi 55 memberikan feedback atau umpan balik kepada pengelola cafe Rumah Kopi 55 menggunakan selambar kertas atau menyampaikan secara lisan kepada pihak pengelola. Penyampaian feedback yang masih menggunakan lisan berakibat kepada pihak pengelola cafe yang minimnya informasi tentang pelayanan yang ada di cafe, apakah pelayanan secara baik atau sebaliknya, sehingga pihak pengelola tidak dapat melakukan evaluasi pelayanan secara maksimal. Oleh sebab itu diharapkan dengan adanya pelatihan pembuatan Google Form ini dapat memudahkan pengelola cafe Rumah Kopi 55 dalam menerima informasi masukkan yang 
diberikan oleh pelanggan. Sedangkan bagi konsumen, dapat memudahkan konsumen dalam menyampaikan masukkan kepada pengelola cafe Rumah Kopi 55.

Dari uraian diatas dapat disimpulkan sebagai permasalahan yang dihadapi oleh pengelola Rumah Kopi 55 adalah sulitnya menerima masukkan dari pelanggan dan kurangnya informasi yang diperoleh oleh pengelola cafe Rumah Kopi 55 sehingga kurang maksimalnya dalam evaluasi pelayanan.

\section{METODE}

Kegiatan dilaksanakan pada Jumat, tanggal 11 Desember 2020. Metode pelaksanaan kegiatan yang dilakukan di Cafe Rumah Kopi 55 adalah dengan memberikan presentasi, interaksi dan diikuti praktek agar pengelola Cafe Rumah Kopi 55 dapat membuat layanan feedback kepada pelanggan melalui aplikasi Google Form. Hal ini dilakukan adalah untuk dijadikan sebagai sentra informasi guna untuk evaluasi pelayanan di Cafe Rumah Kopi 55, pemberian materi diakhiri dengan sesi Tanya jawab dan foto bersama dengan pengelola dan seluruh karyawan Cafe Rumah Kopi 55.

Tabel 1. Metode pelaksanaan yang dilakukan

\begin{tabular}{|c|c|c|}
\hline No & Nama Tahapan & Solusi yang ditawarkan \\
\hline 1. & Perjanjian awal & $\begin{array}{l}\text { Penandatanganan surat kesepakatan perjanjian } \\
\text { kerjasama antara Tim Pengelola Cafe Rumah Kopi } 55\end{array}$ \\
\hline 2. & Jenis Pelatihan & Pembuatan Google Form \\
\hline 3. & $\begin{array}{l}\text { Penentuan Lokasi } \\
\text { Pelatihan }\end{array}$ & Cafe Rumah Kopi 55 \\
\hline 4. & Jumlah Peserta & 25 Peserta \\
\hline 5. & Lama Pelatihan & 3 Hari \\
\hline 6. & Monitoring & $\begin{array}{l}\text { Pendampingan dalam pelatihan Pembuatan aplikasi } \\
\text { Google Form }\end{array}$ \\
\hline 7. & Evaluasi & Pembuatan dan penggunaan aplikasi Google Form \\
\hline
\end{tabular}

\section{HASIL PEMBAHASAN DAN DAMPAK}

Kegiatan Pengabdian Kepada Masyarakat (PKM) di Cafe Rumah Kopi 55 yang berada di di Jalan Beringin 3 No.55, Helvetia, Kec. Medan Helvetia, Kota Medan, Sumatera Utara menghasilkan beberapa luaran yang langsung dapat dirasakan oleh mitra penerima program diantaranya adalah :

1. Pembuatan E-Mail

Pembuatan e-mail merupakan salah satu langkah awal dalam membuat sebuah aplikasi Google Form, karena dengan adanya e-mail, pihak aplikasi dapat mengirimkan hasil yang telah diberikan pelanggan kepada pengelola cafe. 
2. Pembuatan Aplikasi Google Form

Dengan pembuatan aplikasi ini pihak pengelola cafe dapat mengetahui kekurangan dan kelebihan yang ada dicafe tersebut, diantaranya pelayanan terhadap pelanggan, makanan yang disukai pelanggan, dan kekurangan yang lainnya.

3. Pelatihan Dalam Menjalankan Aplikasi Google Form

Dengan pelatihan yang diberikan kepada pihak pengelola cafe, pihak pengelola cafe dapat memasukkan pertanyaan-pertanyaan yang ingin ditanyakan ke pada pelanggan yang makan di cafe rumah kopi 55.

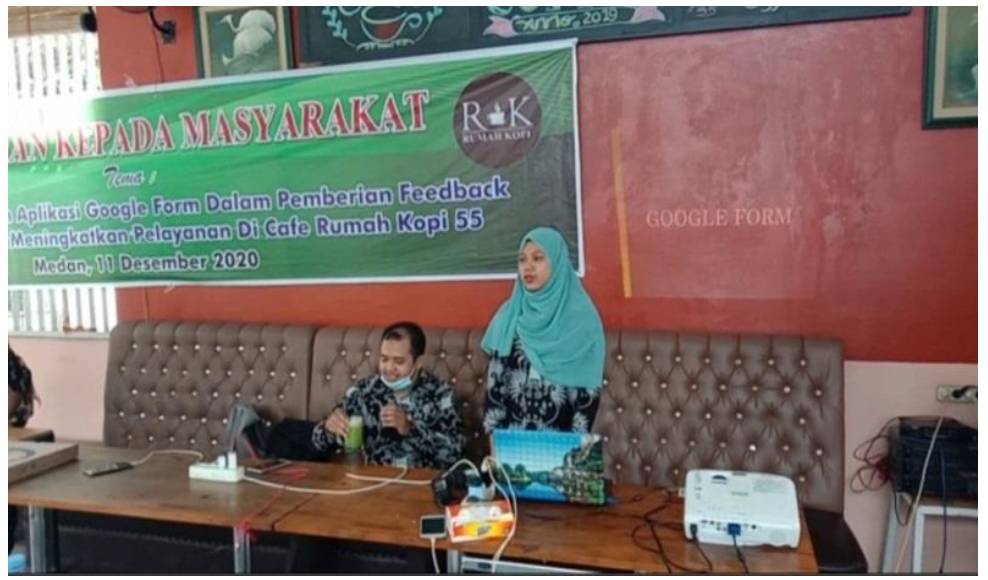

Gambar 1: Penjelasan Tentang Google Form

Pada gambar 1, dilakukan sosialisasi Google Form dalam pembuatan feedback kepada cafe Rumah Kopi 55 sebagai bentuk pengenalan terhadap aplikasi yang akan digunakan.

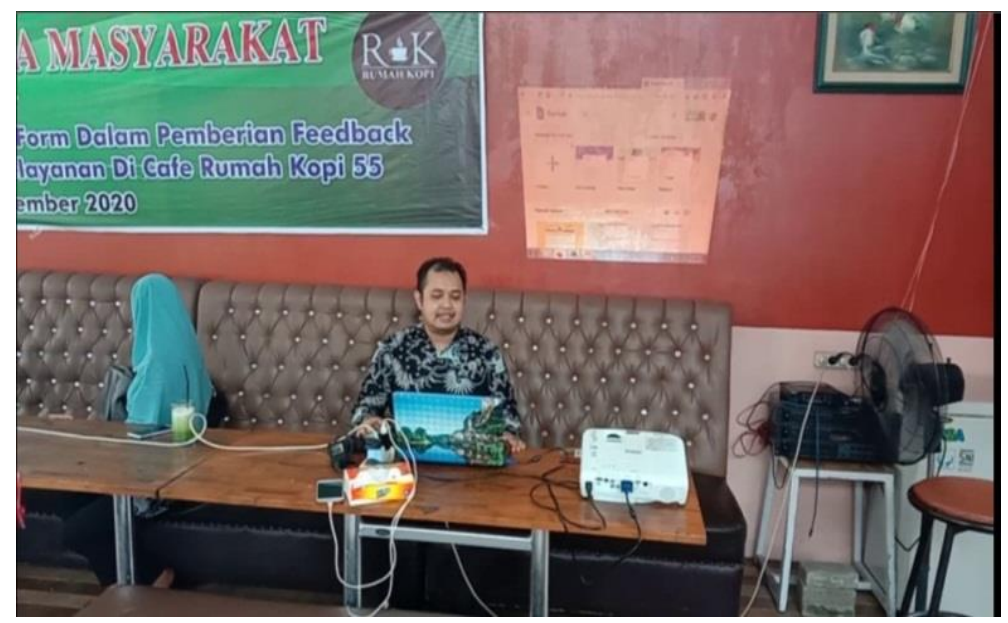

Gambar 2: Pelatihan Pembuatan Google Form

Pada gambar 2, dilakukan pelatihan penggunaan Google Form. Pelatihan tersebut meliputi teknik membangun feedback menggunakan Google Form dan tata cara penggunaan Google Form dalam pengelolaan feedback. 
Pengabdian Kepada Masyarakat yang dilaksanakan oleh dosen tim pengabdian Universitas Dharmawangsa menghasilkan outcome yang dapat dirasakan oleh mitra (Cafe Rumah Kopi 55) antara lain adalah:

1. Pihak pengelola cafe dapat mengetahui secara langsung keluhan pelanggan pada saat ada pelanggan mengunjungi cafe

2. Pihak pengelola cafe tidak lagi perlu mencetak formulir untuk dibagikan ke pelanggan, semuanya dijadikan online bahkan tabulasi hasilnya pun otomatis dan sudah online

3. Feedback yang diberikan kepelanggan dapat dikses lebih dari 50 orang dalam satu berkas dan dalam satu waktu.

Dalam pelaksanaan Pengabdian Kepada Masyarakat (PKM) di Cafe Rumah Kopi 55 beralamat di Jalan Beringin 3 No.55, Helvetia, Kec. Medan Helvetia, Kota Medan, Sumatera Utara, tim pengabdian Universitas Dharmawangsa juga menghadapi kendalakendala yang tidak dapat dihindari antara lain :

1. Lokasi Cafe yang kurang luas sehingga harus bergabung dengan pelanggan yang lagi makan di cafe

2. Adanya pandemic covid-19 sehingga kegiatan pelatihan kepada pihak pengelola cafe harus betul-betul menerapkan protocol kesehatan.

3. Adanya pembatasan kunjungan terhadap pelanggan dikarenakan pandemic covid19

Faktor pendukung Pengabdian kepada Masyarakt ( PKM ) Cafe Rumah Kopi 55 beralamat di Jalan Beringin 3 No.55, Helvetia, Kec. Medan Helvetia, Kota Medan, Sumatera Utara, sehingga dapat berjalan dengan baik adalah kemauan dan tekad dari semua pihak (pihak pengelola dan para waiters) untuk memajukan dunia bisnis khususnya di cafe rumah kopi 55. 


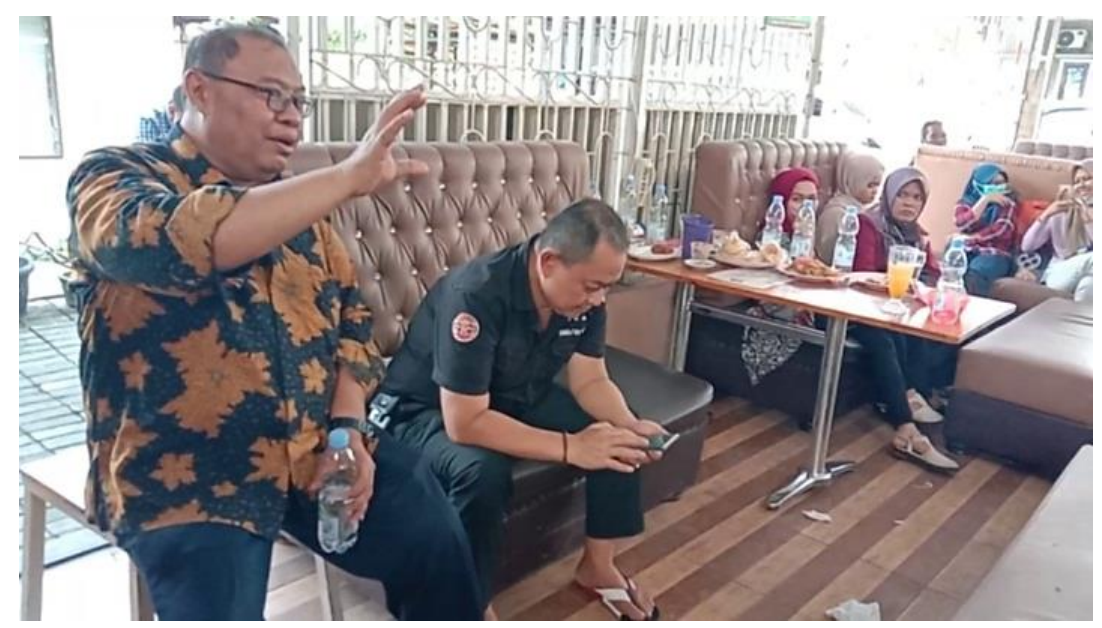

Gambar 3: Tanya Jawab peserta PKM

Pada gambar 3, dilakukan sesi diskusi dan tanya jawab dalam rangka meningkatkan manfaat serta nilai guna pada feedback yang telah dibangun.

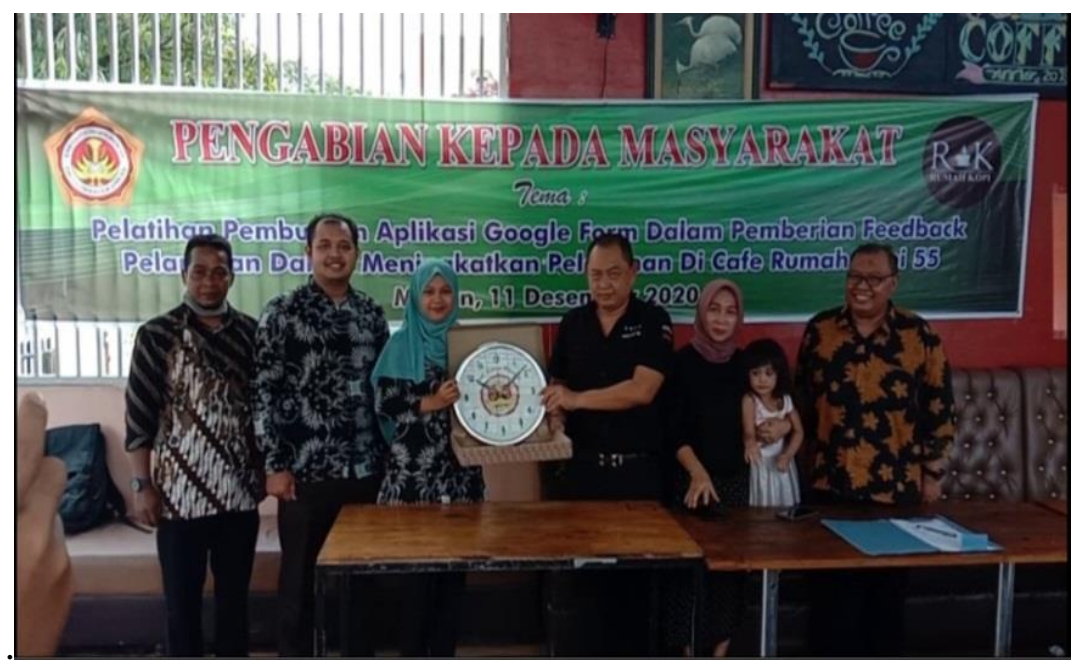

Gambar 4: Foto bersama dengan Mitra

Pada gambar 4, dilakukan sesi foto bersama serta menyerahkan Google Form berupa feedback yang telah dibangun kepada cafe Rumah Kopi 55. Dampak yang diberikan dari pelaksanaan kegiatan ini adalah Bagi konsumen, memberikan kemudahan dalam memberikan feedback dalam pelayanan serta pengelolaan pada cafe Rumah Kopi 55 dan Bagi mitra, memberikan kemudahan dalam pengelolaan feedback serta menjadi landasan untuk meningkatkan pelayanan, manajemen, dan daya saing pada cafe Rumah Kopi 55.

Kegiatan ini menghasilkan suatu evaluasi dari penggunaan Google Form dalam pemberian feedback yang telah dibangun. Responden yang dihasilkan sebanyak 20 (dua puluh) responden dan hasil evaluasi dapat dilihat pada grafik berikut : 
Apakah penggunaan feedback google form dapat memberikan kemudahan dalam memberikan masukkan dan saran terhadap layanan Cafe Rumah Kopi 55

20 jawaban

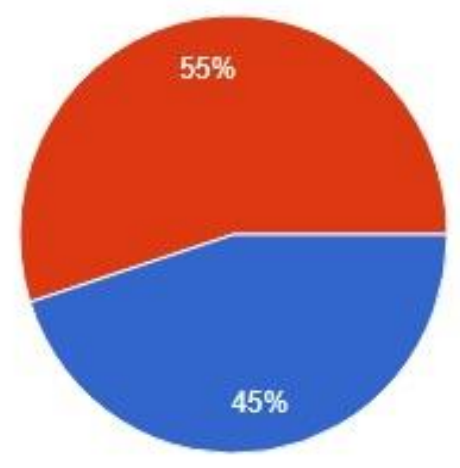

Tidak Mudah

\section{Gambar 5. Hasil Evaluasi Pertanyaan ke 1}

Pada gambar 5, hasil evaluasi mengenai kemudahaan dalam memberikan masukkan dan saran dalam penggunaan feedback Google Form terhadap layanan Cafe Rumah Kopi 55 sebanyak $45 \%$ menjawab sangat mudah dan 55\% menjawab cukup mudah.

\section{Apakah penggunaan feedback google form mudah digunakan? \\ 20 jawaban}

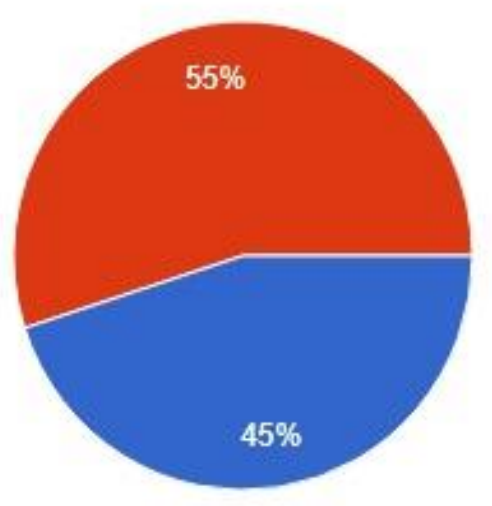

Gambar 6. Hasil Evaluasi Pertanyaan ke 2

Pada gambar 6, evaluasi penggunaan feedback Google Form mudah digunakan sebanyak $45 \%$ menjawab sangat mudah dan $55 \%$ menjawab cukup mudah. 


\section{Apakah penggunaan feedback google form mudah dipahami dalam memberikan masukkan dan saran? \\ 20 jawaban}
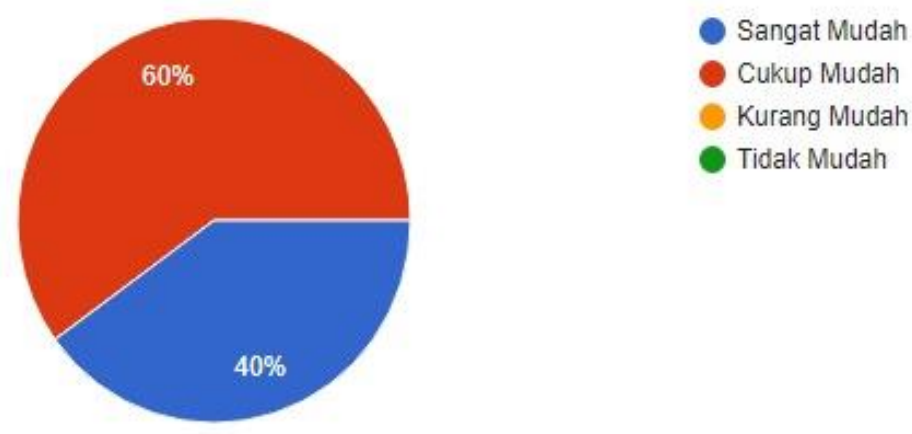

Cukup Mudah

Kurang Mudah

Tidak Mudah

Gambar 7. Hasil Evaluasi Pertanyaan ke 3

Pada gambar 7, hasil responden dalam penggunaan feedback Google Form mudah dipahami dalam memberikan masukkan dan saran pada Cafe Rumah Kopi 55 sebanyak $40 \%$ menjawab sangat mudah dan $60 \%$ menjawab cukup mudah.
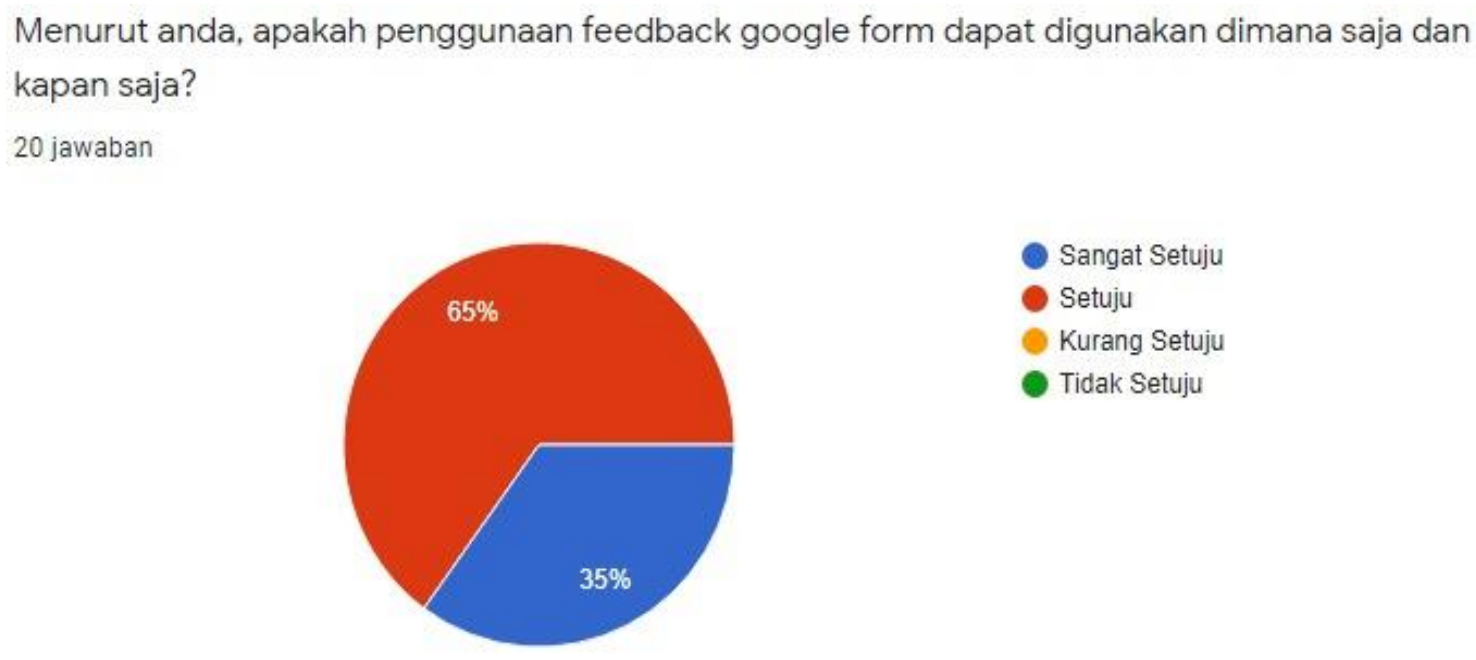

Sangat Setuju

Setuju

Kurang Setuju

Tidak Setuju

Gambar 8. Hasil Evaluasi Pertanyaan ke 4

Pada gambar 8, penggunaan feedback Google Form dapat digunakan secara fleksibel berdasarkan tempat dan waktu menghasilkan $35 \%$ menjawab sangat setuju dan $65 \%$ menjawab setuju. 
Menurut anda, apakah penggunaan feedback google form dapat menyelesaikan permasalahan pengisian feedback sebelumnya?

20 jawaban

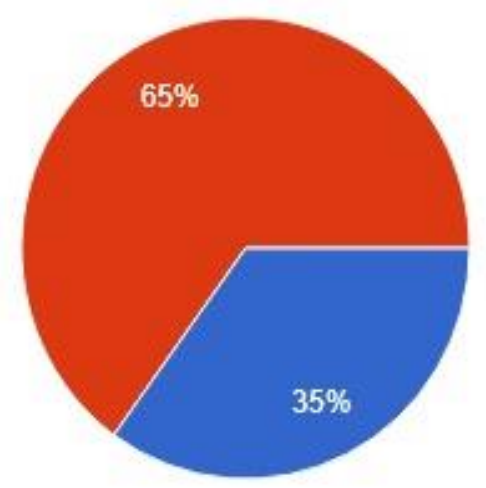

Sangat Setuju

Setuju

Kurang Setuju

Tidak Setuju

Gambar 9. Hasil Evaluasi Pertanyaan ke 5

Pada gambar 9, responden dalam penggunaan feedback Google Form dapat menyelesaikan permasalahan pengisian feedback sebelumnya menghasilkan 35\% menjawab sangat setuju dan $65 \%$ menjawab setuju.

\section{SIMPULAN}

Dari kegiatan Pengabdian yang dilakukan ini pemilik cafe kopi rumah 55 dapat menemukan suatu solusi dalam pemberian feedback atau umpan balik sebagai sarana pengelolaan dan peningkatan layanan serta pihak cafe Rumah Kopi 55 menerima suatu bentuk contoh Google Form berupa feedback atau umpan balik. Bentuk pelatihan dan sosialisasi yang diberikan adalah salah satu cara mempermudah masyarakat memberikan feedback sehingga pihak pengelola cafe tidak perlu lagi menggunakan kertas untuk mengetahui feedback dari pelanggan.

Sementara untuk kampus Universitas Dharmawangsa sebagai ajang promosi dan pengenalan kampus swasta yang ada di Sumatera Utara khususnya Kota Medan.

\section{UCAPAN TERIMA KASIH}

Alhamdulillah Puji syukur kepada Allah swt, karena kehendak dan ridha-Nya tim pengabdian dapat menyelesaikan pengabdian ini. Tim menyadari pengabdian ini tidak akan selesai tanpa doa, dukungan dan dorongan dari berbagai pihak. Adapun dalam kesempatan ini tim ingin mengucapkan banyak terima kasih kepada:

1. Yayasan Universitas Dharmawangsa 
2. Dr. H. Zamakhsyari bin Hasballah Thaib, Lc, MA, Selaku Rektor di Universitas Dharmawangsa

3. Dr. Emmy Syafitri, M.Si, Selaku Ketua LPKM Universitas Dharmawangsa

4. Pemilik Cafe Rumah Kopi 55

5. Semua pihak yang tidak dapat disebutkan satu persatu, terima kasih atas segalanya.

\section{DAFTAR PUSTAKA}

Azis, T. N., \& Shalihah, N. M. (2020). Pengembangan Evaluasi Pembelajaran Berbasis Google Form. Tawazun: Jurnal Pendidikan Islam, 13(1), 54-65. doi: $\underline{10.32832 / \text { tawazun.v13i1.3028 }}$

Iriawan, H. Manajemen Merek \& Kepuasan Pelanggan. Penerbit NEM. 2021. Pekalongan. url:

https://books.google.nl/books?id=ydQxEAAAQBAJ\&printsec=frontcover\&hl=id\#v $=$ onepage \&q\&f=false

Nuryuniarti, R. (2019). Analisis Tingkat Kepuasan Mahasiswa terhadap Kualitas Pelayanan Universitas Muhammadiyah Tasikmalaya. Business Innovation and Entrepreneurship Journal, 1(3), 158-165.

Qwords (2020, 27 Mei). Mengenal Google Form: Pengertian, Kegunaan \& Pembuatan. Dikutip 8 Januari 2021 dari Website https://qwords.com/blog/mengenal-googleform/.

Santilo, K. L. (2018). Google Forms in the Classroom(First Ed.). CreateSpace Independent Publishing Platform.

Technology, Serba Serbi (2016, 16 Agustus). Mengenal Google Form untuk Kebutuhan Survey Anda. Dikutip 8 Januari 2021 dari Website https://idcloudhost.com/mengenal-google-form-untuk-kebutuhan-survey-anda/.

Tedas (2020, 11 Oktober). Feedback: Pengertian Jenis dan Cara Menyampaikannya. Dikutip 8 Januari 2021 dari website https://tedas.id/bisnis/umum/feedback/.

Widayanti, Tri. (2021). Use of Google Form in Support of Data Collection for Student Scientific Work. JUDIMAS. 1. 85. doi:10.30700/jm.v1i1.1015 